\title{
IDENTIFIKASI PENGGUNAAN OBAT PADA PASIEN DIABETES MELLITUS TIPE II USIA LANJUT DENGAN BEER'S CRITERIA DI INSTALASI RAWAT INAP RUMAH SAKIT IBNU SINA MAKASSAR PERIODE TAHUN 2012
}

\author{
Rizqi Nur Azizah, A. Hudayah \\ Fakultas Farmasi,Universitas Muslim Indonesia Makassar \\ Email: rizqi.azizah@umi.ac.id
}

\begin{abstract}
Using identification in the use medicine with Beer's Criteria to the advanced age patients in Inpatient installation in Ibnu Sina Makassar Hospital which aims to observe, report, and identify in the use medicine in elderly patient of Type II Diabetes Mellitus are covered by Beer's Criteria in inpatient installation in Ibnu Sina Makassar Hospital period 2012. This is a descriptive research by collecting data retrospectively. The results of this research concluded in the use medicine there are 8 types of drugs covered by the Beer's Criteria, they are alprazolam 14.28\%, insulin $64.28 \%$, gliburide (gluconic $^{\circledR}$ ) $1.19 \%$, metoclopramide (sotatic $^{\circledR}$ ) $4.76 \%$, Kal. Diklofenak (kataflam ${ }^{\circledR}$ ) 1.19\%, mefenamic acid 3.57\%, meloxicam $2.38 \%$, and ketorolak $8.33 \%$.
\end{abstract}

Keyword : Beer's Criteria, Elderly, Type II Diabetes Mellitus.

\section{PENDAHULUAN}

Pada usia 60 tahun ke atas terjadi proses penuaan yang bersifat universal berupa kemunduran dari fungsi biosel, jaringan, organ, bersifat progesif, perubahan secara bertahap, akumulatif, dan intrinsik. Proses penuaan mengakibatkan terjadinya perubahan pada berbagai organ di dalam tubuh seperti sistem gastrointestinal, sistem genitourinaria, sistem endokrin, sistem immunologis, sistem serebrovaskular, sistem saraf pusat dan sebagainya. ${ }^{1}$
Diabetes mellitus merupakan suatu penyakit atau gangguan metabolisme kronis yang ditandai dengan tingginya kadar gula darah, disertai dengan gangguan metabolisme karbohidrat, lipid, dan protein sebagai akibat insufisiensi fungsi insulin. Salah satu farmasis di Rumah Sakit Ibnu Sina mengatakan bahwa penyakit diabetes mellitus merupakan salah satu penyakit yang banyak terjadi pada pasien usia lanjut dan menjalani rawat inap di rumah sakit tersebut, sehingga dibutuhkan perawatan dan pengobatan secara 
Identifikasi Penggunaan Obat Pada Pasien Diabetes Mellitus Tipe li Usia Lanjut Dengan Beer's Criteria Di Instalasi Rawat Inap Rumah Sakit Ibnu Sina Makassar Periode Tahun 2012

teratur guna menjaga agar kadar glukosa plasma berada dalam kisaran normal dan mencegah atau meminimalkan kemungkinan timbulnya penyakit lain.

Pemberian obat pada pasien usia lanjut perlu dipertimbangkan beberapa hal antara lain adalah pengaturan dosisnya karena pada usia lanjut, seorang pasien lebih mudah mengalami reaksi efek samping dan interaksi obat yang merugikan. Serta pada usia lanjut, rentan terserang penyakit sehingga pemberian obat sering polifarmasi. Polifarmasi berarti pemakaian banyak obat sekaligus pada seorang pasien, lebih dari yang dibutuhkan secara logis-rasional dihubungkan dengan diagnosis yang diperkirakan. ${ }^{1}$

Perubahan fisiologi tubuh pada usia lanjut berpengaruh terhadap terapi obat baik farmakokinetik maupun farmakodinamik, sehingga memungkinkan terjadi peningkatan efek yang tidak dikehendaki terhadap penggunaan obat. Beer's Criteria merupakan salah satu perangkat tentang ketidak sesuaian pengobatan yang mencakup obat-obat yang sebaiknya tidak digunakan atau dapat digunakan dengan perhatian khusus pada pasien usia lanjut. ${ }^{2}$ Beer's
Criteria telah digunakan di beberapa negara sebagai referensi dokter dan apoteker untuk meningkatkan kualitas pengobatan pada pasien usia lanjut.

Berdasarkan hal tersebut, maka dilakukan penelitian terkait permasalahan penggunaan obat pada pasien usia lanjut di Rumah Sakit Ibnu Sina Makassar dengan parameter Beer's Criteria untuk meminimalkan terjadinya efek yang tidak dikehendaki.

\section{METODE PENELITIAN}

Penelitian ini dilakukan secara deskriptif pada pasien usia lanjut (60 tahun keatas) dengan diagnosis diabetes mellitus tipe II yang menjalani rawat inap di Rumah Sakit Ibnu Sina Makassar periode tahun 2012 dengan penelusuran data secara retrospektif terhadap penggunaan obat berdasarkan Beer's Criteria.

\section{HASIL PENELITIAN}

Hasil penelitian disajikan secara berurutan sesuai dengan analisis data yang telah dilakukan yaitu meliputi distribusi pasien, profil pengobatan, dan penggunaan obat dalam cakupan Beer's Criteria yang terjadi di Rumah Sakit Ibnu Sina Makassar periode tahun 2012. Distribusi Pasien Berdasarkan Jenis Kelamin dapat kita lihat pada tabel 1: 
Identifikasi Penggunaan Obat Pada Pasien Diabetes Mellitus Tipe Ii Usia Lanjut Dengan Beer's Criteria Di Instalasi Rawat Inap Rumah Sakit Ibnu Sina Makassar Periode Tahun 2012

Tabel 1. Distribusi Jenis Kelamin Pasien Diabetes Mellitus Tipe II Di Instalasi Rawat Inap Rumah Sakit Ibnu Sina Makassar Periode Tahun 2012

\begin{tabular}{cccc}
\hline No. & Jenis kelamin & Jumlah (orang) & Persentase (\%) \\
\hline 1. & Perempuan & 23 & 54,76 \\
2. & Laki- laki & 19 & 45,23 \\
\hline & Total & $\mathbf{4 2}$ & $\mathbf{1 0 0}$ \\
\hline
\end{tabular}

Hasil data profil pengobatan jenis obat. Penggunaan obat-obat penyakit diabetes mellitus tipe II yang terjadi di Rumah Sakit Ibnu Sina penyakit diabetes mellitus tipe II yang Makassar periode tahun 2012 digunakan di Rumah Sakit Ibnu Sina dilakukan berdasarkan golongan dan

Makassar dapat kita lihat pada tabel 2:

Tabel 2. Jumlah Penggunaan Obat Antidiabetik Pada Pasien Diabetes Mellitus Tipe II Usia Lanjut Di Instalasi Rawat Inap Rumah Sakit Ibnu Sina Makassar Tahun 2012.

\begin{tabular}{|c|c|c|c|c|c|c|}
\hline No & $\begin{array}{c}\text { Obat } \\
\text { antidiabetik }\end{array}$ & Golongan & $\begin{array}{l}\text { Nama obat } \\
\text { (generik) }\end{array}$ & Nama paten & Jumlah & $\begin{array}{c}\text { Persentase } \\
(\%)\end{array}$ \\
\hline \multirow{5}{*}{1.} & \multirow{4}{*}{ Insulin } & Kerja panjang & Insulin glargine & Lantus $^{(}$ & 22 & 30,55 \\
\hline & & Kerja singkat & Insulin aspart & Novorapid $^{(\Theta)}$ & 25 & 34,72 \\
\hline & & Kerja panjang & Insulin detemir & Levemir $^{(\theta)}$ & 5 & 6,94 \\
\hline & & $\begin{array}{l}\text { Kerja sedang, } \\
\text { mula kerja cepat }\end{array}$ & Insulin aspart & Novomix $^{\circledR}$ & 2 & 2,77 \\
\hline & \multicolumn{4}{|c|}{ Jumlah } & 54 & 74,98 \\
\hline \multirow{5}{*}{2.} & \multirow{3}{*}{$\begin{array}{l}\text { Antidiabetik } \\
\text { oral }\end{array}$} & Biguanida & Metformin & Glucopage $^{\circledast}$ & 9 & 12,5 \\
\hline & & \multirow[t]{2}{*}{ Sulfonilurea } & Glimepirid & Amaryl ${ }^{(\circledast)}$ & 8 & 11,11 \\
\hline & & & $\begin{array}{c}\text { Gliburida } \\
\text { (glibenklamid) }\end{array}$ & Gluconic $^{\circledR}$ & 1 & 1,38 \\
\hline & \multicolumn{4}{|c|}{ Jumlah } & 18 & 24,99 \\
\hline & \multicolumn{4}{|c|}{ Total } & 72 & 100 \\
\hline
\end{tabular}

Dan penggunaan obat-obat lain yang digunakan di Rumah Sakit Ibnu Sina Makassar untuk mengobati penyakit-penyakit penyerta yang dialami masing-masing pasien dapat dilihat pada tabel 3: 
Identifikasi Penggunaan Obat Pada Pasien Diabetes Mellitus Tipe li Usia Lanjut Dengan Beer's Criteria Di Instalasi Rawat Inap Rumah Sakit Ibnu Sina Makassar Periode Tahun 2012

Tabel 3. Jumlah Penggunaan Obat Selain Antidiabetik Pada Pasien Diabetes Mellitus Tipe II Usia Lanjut Di Instalasi Rawat Inap Rumah Sakit Ibnu Sina Makassar Tahun 2012

\begin{tabular}{|c|c|c|c|c|c|}
\hline No & Kelas terapi & $\begin{array}{l}\text { Nama obat } \\
\text { (Generik) }\end{array}$ & $\begin{array}{l}\text { Nama } \\
\text { paten }\end{array}$ & $\begin{array}{l}\text { Jumlah } \\
\text { pasien }\end{array}$ & $\begin{array}{r}\text { Persent } \\
(\%)\end{array}$ \\
\hline \multirow{5}{*}{1.} & \multirow{5}{*}{ Antimigrain } & Flunarizina & Frego $^{\circledR}$ & 2 & 0,94 \\
\hline & & Ko-dergokrina mesilat & Ergotika $^{\circledR}$ & 1 & 0,47 \\
\hline & & 200 mg, Vit- B12 250 & Neurodex ${ }^{\circledR}$ & 2 & 0,9 \\
\hline & & Vit- B1 100 mg, Vit- B6 & & 3 & \\
\hline & & $\begin{array}{c}100 \text { mg, Vit- B12 } 5000 \\
\text { mcg }\end{array}$ & Sohobion $^{\circledR}$ & & 1,4 \\
\hline \multirow[t]{6}{*}{2.} & \multirow[t]{6}{*}{$\begin{array}{l}\text { Vitamin dan } \\
\text { mineral }\end{array}$} & Vit- B1 $100 \mathrm{mg}$, Vit- B6 & & & \\
\hline & & $\begin{array}{c}200 \text { mg, Vit- B12 } 250 \\
\text { mcg }\end{array}$ & Neurobion ${ }^{\circledR}$ & 1 & 0,47 \\
\hline & & $\begin{array}{c}\text { Mecobalamin } 500 \mathrm{mcg} \text {, } \\
\text { vit B1 } 100 \mathrm{mg} \text {, vit B6 } \\
200 \mathrm{mg}\end{array}$ & Rebal plus ${ }^{\circledR}$ & 1 & 0,4 \\
\hline & & Essensial ketoacid & Prorenal ${ }^{\circledR}$ & 1 & 0,4 \\
\hline & & Ranitidine & & 7 & 3,3 \\
\hline & & Pantoprazole & Pranza $^{\circledR}$ & 3 & 1,4 \\
\hline \multirow{5}{*}{3.} & \multirow{5}{*}{$\begin{array}{c}\text { Antitukak } \\
\text { (antasidum) }\end{array}$} & Lansoprazol & & 2 & 0,9 \\
\hline & & Amenrazolo & $\mathrm{Ozid}^{(\Theta)}$ & 3 & 1,4 \\
\hline & & umeprazole & Gastrofer $^{\circledR}$ & 4 & 1,8 \\
\hline & & Sukralfat & Inpepsa $^{\circledR}$ & 1 & 0,4 \\
\hline & & Ceftriaxon & & 12 & 5,6 \\
\hline \multirow{3}{*}{4.} & Antibiotik & Sefiksim & & 2 & 0,9 \\
\hline & gol.sefalosporin & Cefadroxil & & 3 & 1,4 \\
\hline & & Cefotaxime & & 3 & 1,4 \\
\hline 5. & $\begin{array}{l}\text { Antibiotik gol. } \\
\text { Penicillin }\end{array}$ & Amoxicillin & $\operatorname{Amoxan}^{\circledR}$ & 1 & 0,4 \\
\hline \multirow[t]{2}{*}{6.} & $\begin{array}{l}\text { Antibiotik gol. } \\
\text { Karbapenem }\end{array}$ & Meropenem & & 1 & 0,47 \\
\hline & Antibiotik gol. & Ciprofloxacin & & 4 & 1,89 \\
\hline \multirow[t]{2}{*}{7.} & Fluorokuinolon & I ovefloyasin & Cravit $^{\circledR}$ & 2 & 0,9 \\
\hline & & Levofloxacın & Levores $^{\circledR}$ & 1 & 0,4 \\
\hline \multirow{4}{*}{8.} & Antibiotik gol. Lain & Klindamisin & & 2 & 0,9 \\
\hline & & Metronidazol & & 7 & 3,3 \\
\hline & & Parasetamol & Sanmol ${ }^{\circledR}$ & 6 & 2,8 \\
\hline & & Ketorolak & & $\begin{array}{l}4 \\
7\end{array}$ & $\begin{array}{l}1,8 \\
3,3\end{array}$ \\
\hline \multirow[t]{4}{*}{9.} & Analgesik non & Kalium diklofenak & Kataflam $^{\circledR}$ & 1 & 0,4 \\
\hline & & Meloxicam & & 2 & 0,9 \\
\hline & & Asam mefenamat & & 3 & 1,4 \\
\hline & & Metampiron & Novalgin $^{\circledR}$ & 2 & 0,9 \\
\hline \multirow[t]{2}{*}{10.} & Analgesik opioid & Codein & & 3 & 1,4 \\
\hline & & & Merislon ${ }^{\circledR}$ & 1 & 0,4 \\
\hline \multirow[t]{2}{*}{11.} & Antivertigo & Betahistin mesilat & Mertigo ${ }^{\circledR}$ & 5 & 2,3 \\
\hline & & & Vastigo $^{\circledR}$ & 1 & 0,47 \\
\hline
\end{tabular}


Identifikasi Penggunaan Obat Pada Pasien Diabetes Mellitus Tipe li Usia Lanjut Dengan Beer's Criteria Di Instalasi Rawat Inap Rumah Sakit Ibnu Sina Makassar Periode Tahun 2012

12. Antiemetik

13. Antihiperlipidemi

14. Hipnotik dan ansiolitik

15. Antihipertensi

16. Kortikoidum

17. Neuromialgikum

18. Antitusif, expectorant

19. Laxativum dan
purgativum
20. Antialergi
21. Antiplatelet
22. Trombotik
23. Vasodilator

24. Hemostiptikum

25. Metabolitropikum

26. Antiepileptikum

\section{Betahistin dihidroklorida Ondansetron}

Metoklopramid

Domperidon

Simvastatin Kalsium atorvastatin

Alprazolam

Amlodipin

Furosemid

Valsartan

Telmisartan

Telisartan

+amlodipin

Lisinopril

Irbesartan

Ramipril

Dexamethasone

Metil prednisolon

Mekobalamin

Bromheksin $\mathrm{HCl}$

Ambroxol

Dextrometorphan

Oksomemazin

Loperamid $\mathrm{HCl}$

Tiap $5 \mathrm{mg}$

emulsi,fenolftalein 55

mg, paraffin cair 1200

$\mathrm{mg}$, gliserin $378 \mathrm{mg}$, jeli

$$
9,4 \mathrm{mg}
$$

Mebhidrolina napadisilat

Asam asetilsalisilat

Clopidogrel

Isosorbida dinitrat

Karbazokrom Na.

sulfonat

Asam traneksamat

Citicolyn

Piracetam

Betaserc $^{\circledR}$
Sotatic $^{\circledR}$
Primperan $^{\circledR}$
Vometa $^{\circledR}$
Vosedon $^{\circledR}$

0,47

3,31

0,94

0,94

0,94

0,47

3,79

Lipitor $^{\circledR} \quad 1$

0,47

12

5,68

Amdixal $^{\circledR} \quad 11$

5,21

0,94

0,47

0,47

1,89

0,47

0,47

Twinsta $^{\circledR} \quad 1$

0,47

Tensinop $^{\circledR}$

0,94

0,94

0,47

0,47

Hexilon $^{\circledR} \quad 1$

0,94

Bisolvon $^{\circledR} \quad 2$

0,94

$\begin{array}{cc} & 5 \\ \text { Contusyl }^{\circledR} & 1 \\ \text { Lodia }^{\circledR} & 1\end{array}$

2,36

0,47

0,47

0,47

Laxadine $^{\circledR} \quad 3$

1,42

Interhistin $^{\circledR} \quad 3 \quad 1,42$

$\begin{array}{lll}\text { Aspilet }^{\Theta} & 7 & 3,31\end{array}$

Vaclo $^{\circledR} \quad 4$

1,89

Farsorbid $^{\circledR} \quad 3$

1,42

Adona $^{\circledR} \quad 2$

0,94

Brainact $^{\circledR}$

Neurotam $^{\circledR} \quad 1$

0,47

0,94

0,47

Ursodeoksilat

Urdafalk $^{\circledR} \quad 1$

0,47

Gabapentin

Nephatic $^{\circledR}$

Total

211

Hasil analisis data untuk Beer's Criteria yang terjadi pada penggunaan obat dalam cakupan pasien usia lanjut penyakit diabetes 
Identifikasi Penggunaan Obat Pada Pasien Diabetes Mellitus Tipe li Usia Lanjut Dengan Beer's Criteria Di Instalasi Rawat Inap Rumah Sakit Ibnu Sina Makassar Periode Tahun 2012

mellitus tipe II di instalasi rawat inap Society Updated Beers Criteria ${ }^{3}$ Rumah Sakit Ibnu Sina Makassar Jumlah obat-obatan Yang Masuk Ke periode tahun 2012 dilakukan Dalam Cakupan Beer's Criteria dapat berdasarkan literatur yang digunakan kita lihat pada tabel 4:

yaitu jurnal American Geriatrics

Tabel 4. Jumlah Penggunaan Obat Pada Pasien Diabetes Mellitus Tipe II Usia Lanjut Yang Masuk Ke Dalam Cakupan Beer's Criteria Di Instalasi Rawat Inap Rumah Sakit Ibnu Sina Makassar Tahun 2012

\begin{tabular}{|c|c|c|c|c|c|c|}
\hline \multirow[b]{2}{*}{ No } & \multirow[b]{2}{*}{$\begin{array}{c}\text { Nama obat } \\
\text { (Paten) }\end{array}$} & \multicolumn{3}{|c|}{ Dosis yang diberikan kepada pasien } & \multirow[b]{2}{*}{ Jumlah } & \multirow[b]{2}{*}{$\begin{array}{c}\text { Persentase } \\
\text { (\%) }\end{array}$} \\
\hline & & Potensi & Frekuensi & $\begin{array}{l}\text { Dosis } \\
\text { Sekali }\end{array}$ & & \\
\hline 1. & $\begin{array}{c}\text { Alprazolam } \\
\text { (Alprazolam }^{\circledR} \text { ) }\end{array}$ & $0,5 \mathrm{mg} /$ tablet & $1 \times 1$ & $0,5 \mathrm{mg}$ & 12 & 14,28 \\
\hline 2. & Insulin & $100 \mathrm{U} / \mathrm{ml}$ & $3 \times 1$ & 12 unit & 54 & 64,28 \\
\hline 3. & $\begin{array}{c}\text { Gliburid } \\
\text { (Gluconic }^{\circledR} \text { ) }\end{array}$ & $5 \mathrm{mg} /$ tablet & $1 \times ` 1$ & $5 \mathrm{mg}$ & 1 & 1,19 \\
\hline 4. & $\begin{array}{l}\text { Metoclopramide } \\
\quad\left(\text { sotatic }^{\circledR}\right)\end{array}$ & $2 \mathrm{ml} /$ ampul & $2 \times 1$ & $2 \mathrm{ml}$ & 4 & 4,76 \\
\hline 5. & $\begin{array}{l}\text { Kal. Diklofenak } \\
\quad\left(\text { kataflam }^{\circledR}\right)\end{array}$ & $25 \mathrm{mg} /$ tablet & $2 \times 1$ & $25 \mathrm{mg}$ & 1 & 1,19 \\
\hline 6. & $\begin{array}{c}\text { Asam mefenamat } \\
(\text { Asam } \\
\left.\text { mefenamat }^{\circledR}\right)\end{array}$ & $500 \mathrm{mg}$ & $3 \times 1$ & $500 \mathrm{mg}$ & 3 & 3,57 \\
\hline 7. & $\begin{array}{c}\text { Meloxicam } \\
\left(\text { Meloxicam }^{\circledR}\right)\end{array}$ & $15 \mathrm{mg}$ & $1 \times 1$ & $15 \mathrm{mg}$ & 2 & 2,38 \\
\hline 8. & $\begin{array}{c}\text { Ketorolak } \\
\left(\text { Ketorolak }^{\circledR}\right)\end{array}$ & $2 \mathrm{ml} /$ ampul & $2 \times 1$ & $2 \mathrm{ml}$ & 7 & 8,33 \\
\hline \multicolumn{5}{|c|}{ Total } & 84 & 100 \\
\hline
\end{tabular}

\section{PEMBAHASAN}

Pada usia lanjut akan terjadi proses menghilangnya kemampuan jaringan untuk memperbaiki diri atau mengganti dan mempertahankan fungsi normalnya secara perlahanlahan sehingga tidak dapat bertahan terhadap infeksi dan memperbaiki kerusakan yang terjadi. Karena itu di dalam tubuh akan menumpuk makin banyak distorsi metabolik dan struktural disebut penyakit degeneratif. Proses penuaan yang terjadi pada usia lanjut merupakan proses alami disertai adanya penurunan kondisi fisik, fisiologi, psikologis maupun sosial yang saling berinteraksi satu sama lain. Perubahan status mental dan faal kognitif turut berperan dalam pencapaian hasil pengobatan. Pengobatan dengan obat untuk usia lanjut harus selalu disertai dengan pertimbangan yang sangat hati-hati terhadap kesehatan dan toleransi individu, seleksi obat, dan jadwal dosis 
Identifikasi Penggunaan Obat Pada Pasien Diabetes Mellitus Tipe li Usia Lanjut Dengan Beer's Criteria Di Instalasi Rawat Inap Rumah Sakit Ibnu Sina Makassar Periode Tahun 2012

serta kemungkinan kebutuhan untuk bantuan dalam pengobatan rutin.

$$
\text { Diabetes mellitus (DM) }
$$

didefinisikan sebagai suatu penyakit atau gangguan metabolisme kronis dengan multi etiologi yang ditandai dengan tingginya kadar gula darah disertai dengan gangguan metabolisme karbohidrat, lipid dan protein sebagai akibat insufisiensi fungsi insulin. Insufisiensi fungsi insulin dapat disebabkan oleh gangguan atau defisiensi produksi insulin oleh sel-sel beta langerhans kelenjar pankreas, atau disebabkan oleh kurang responsifnya sel-sel tubuh terhadap insulin.

Penelitian ini menggunakan data-data dari kartu rekam medis dengan jumlah kasus sebanyak 42 pasien usia lanjut yang menderita penyakit diabetes mellitus tipe II di rumah sakit Ibnu Sina Makassar tahun 2012.

Data pasien diabetes mellitus yang diteliti mempunyai kisaran umur 60 tahun keatas. Dimana jumlah jenis kelamin pasien laki-laki sebanyak 19 pasien dan 23 pasien perempuan dari 42 pasien diabetes mellitus tipe II. Dari data tersebut dapat dilihat bahwa ternyata pasien perempuan sebanyak $54,76 \%$ yang menderita diabetes mellitus tipe II sedangkan pasien lakilaki hanya hanya 45,23\%. Hal ini disebabkan Karena gaya hidup dan pola makan perempuan yang cenderung beresiko diabetes mellitus misalnya diet tinggi lemak dan rendah serat, serta kurangnya aktivitas fisik (olahraga).

Berbagai Golongan obat yang digunakan dalam pengobatan penyakit diabetes mellitus tipe II diantaranya yaitu obat antidiabetik, antivertigo, antitukak, antiemetik, antihiperlipidemia, antibiotik, hipnotik dan ansiolitik, vitamin dan mineral, antihipertensi, antiinflmasi, analgesik, neuromialgikum, antitusif dan expektoran, laxativum, antialergi, antiplatelet, trombolitik, vasodilator koroner, hemostiptikum, dan metabolitropikum. Obat yang diberikan bermacam-macam, hal ini karena adanya penyakit lain yang diderita oleh pasien.

Pada penelitian ini obat-obatan antidiabetik yang digunakan yaitu obat hipoglikemik oral dan insulin. Diantaranya yaitu metformin dari golongan biguanida sebesar (12,5\%), gliburid dan glimepirid dari golongan sulfonilurea sebesar $(1,38 \%)$ dan $(11,11 \%)$, levemir $^{\circledR}(6,94 \%)$, lantus $^{\circledR}$ 
Identifikasi Penggunaan Obat Pada Pasien Diabetes Mellitus Tipe li Usia Lanjut Dengan Beer's Criteria Di Instalasi Rawat Inap Rumah Sakit Ibnu Sina Makassar Periode Tahun 2012

$(30,55 \%)$, novorapid ${ }^{\circledR}(34,72 \%)$, dan novomix ${ }^{\circledR}(2,77 \%)$.

Pada keadaan tertentu, diperlukan terapi kombinasi dari obat hipoglikemik oral dengan insulin dikarenakan target glikemia yang tidak tercapai atau kadar glukosa tidak terkontrol dengan baik.

Obat antidiabetik oral yang paling banyak digunakan adalah metformin dari golongan biguanida. Metformin di rekomendasikan sebagai terapi farmakologi awal yaitu pada keadaan tidak terdapat kontraindikasi spesifik, karena efeknya yang langsung terhadap glikemia. Metformin menurunkan produksi glukosa di hepar dan meningkatkan sensitivitas jaringan otot dan adiposa terhadap insulin. Bila dengan intervensi pola hidup dan metformin dosis maksimal yang dapat ditolerir target glikemia tidak tercapai atau tidak dapat dipertahankan, sebaiknya ditambah obat lain setelah 2-3 bulan memulai pengobatan atau setiap saat bila target $\mathrm{A} 1 \mathrm{C}$ tidak tercapai. Bila terdapat kontraindikasi terhadap metformin atau pasien tidak dapat mentolerir metformin maka perlu diberikan tambahan terapi berupa insulin. Efek samping dari metformin yaitu mual, muntah, diare serta kecap logam (metallic taste), pada pasien yang mengalami gangguan ginjal, pemberian biguanid akan dapat meningkatkan kadar asam laktat dalam darah, sehingga hal ini dapat mengganggu keseimbangan elektrolit dalam cairan tubuh.

Obat hipoglikemik oral golongan sulfonilurea merupakan obat pilihan (drug of choice) untuk penderita diabetes dewasa baru dengan berat badan normal dan kurang serta tidak pernah mengalami ketoasidosis sebelumnya. Senyawa-senyawa sulfonilurea sebaiknya tidak diberikan pada penderita gangguan hati, ginjal dan tiroid. Gliburid dan glimepirid dari golongan sulfonilurea bekerja merangsang sekresi insulin di kelenjar pankreas, oleh sebab itu hanya efektif apabila sel-sel $\beta$ langerhans pankreas masih dapat berproduksi. Penurunan kadar glukosa darah yang terjadi setelah pemberian senyawa-senyawa sulfonilurea disebabkan oleh perangsangan sekresi insulin oleh kelenjar pankreas. Sifat perangsangan ini berbeda dengan perangsangan oleh glukosa, karena ternyata pada saat glukosa (atau kondisi hiperglikemia) gagal merangsang sekresi insulin, senyawa-senyawa obat ini masih mampu meningkatkan sekresi insulin. Oleh sebab itu, obat- 
Identifikasi Penggunaan Obat Pada Pasien Diabetes Mellitus Tipe li Usia Lanjut Dengan Beer's Criteria Di Instalasi Rawat Inap Rumah Sakit Ibnu Sina Makassar Periode Tahun 2012

obat golongan sulfonilurea sangat membantu transport glukosa masuk ke bermanfaat untuk penderita diabetes yang kelenjar pankreasnya masih mampu memproduksi insulin, tetapi karena sesuatu hal terhambat sekresinya. Pada penderita dengan kerusakan sel-sel $\beta$ langerhans kelenjar pankreas, pemberian obatobat hipoglikemik oral golongan sulfonilurea tidak bermanfaat. Pada dosis tinggi, sulfonilurea menghambat degradasi insulin oleh hati.

Insulin mempunyai peran yang sangat penting dan luas dalam pengendalian metabolisme. Insulin yang disekresikan oleh sel-sel $\beta$ pankreas

akan langsung diinfusikan ke dalam hati melalui vena porta, yang kemudian akan di distribusikan ke seluruh tubuh melalui peredaran darah. Efek kerja insulin yang sudah sangat dikenal adalah membantu transport glukosa dari darah ke dalam sel. Kekurangan insulin menyebabkan glukosa darah tidak dapat atau terhambat masuk ke dalam sel. Akibatnya, glukosa darah akan meningkat, dan sebaliknya sel-sel tubuh kekurangan bahan sumber energi sehingga tidak dapat memproduksi energi sebagaimana seharusnya. Di samping fungsinya dalam sel, insulin mempunyai pengaruh yang sangat luas terhadap metabolisme, baik metabolisme karbohidrat dan lipid, maupun metabolisme protein dan mineral. Insulin akan meningkatkan lipogenesis, menekan lipolisis, serta meningkatkan transport asam amino masuk ke dalam sel. Insulin juga mempunyai peran dalam modulasi transkripsi, sintesis DNA dan replikasi sel. Itu sebabnya, gangguan fungsi insulin dapat menyebabkan pengaruh negatif dan komplikasi yang sangat luas pada berbagai organ dan jaringan tubuh.

Dari data yang diperoleh ditemukan bahwa penggunaan insulin lebih banyak yaitu 74,98\% dibandingkan obat hipoglikemik oral hanya $24,99 \%$ pada pengobatan diabetes mellitus tipe II. Pada diabetes tipe II, pankreas dapat memproduksi insulin, setidaknya pada awalnya, tetapi sel-sel tubuh melawan insulin, menyebabkan tubuh harus memproduksi insulin ekstra supaya glukosa masuk ke dalam sel-sel. Bila pankreas tidak bisa lagi menghasilkan cukup insulin untuk menjaga kadar glukosa normal, hal ini akan memicu terjadinya kondisi hiperglikemia. Maka 
Identifikasi Penggunaan Obat Pada Pasien Diabetes Mellitus Tipe li Usia Lanjut Dengan Beer's Criteria Di Instalasi Rawat Inap Rumah Sakit Ibnu Sina Makassar Periode Tahun 2012

dari itu diperlukan terapi insulin untuk memperbaiki kadar gula darah. Selain itu penderita diabetes mellitus tipe II yang gula darahnya tidak dapat dikendalikan dengan diet dan antidiabetik oral juga memerlukan terapi insulin.

Dari analisis data yang telah dilakukan berdasarkan literatur jurnal American Geriatrics Society Updated Beer's Criteria ${ }^{3}$ penggunaan obat dalam cakupan Beer's Criteria ditemukan pada pengobatan penyakit diabetes mellitus tipe II dimana ada 8 macam obat-obatan yang termasuk dalam cakupan Beer's Criteria yaitu alprazolam $14,28 \%$, insulin $64,28 \%$, gliburid $\quad$ (gluconic $^{\circledR}$ ) $1,19 \%$, metoklopramid $\left(\right.$ sotatic $^{\circledR}$ ) 4,76\%, kal. Diklofenak (kataflam ${ }^{\circledR}$ ) 1,19\%, asam mefenamat $3,57 \%$, meloxicam 2,38 $\%$, dan ketorolak $8,33 \%$.

Berdasarkan

American

Geriatrics society Alprazolam merupakan obat hipnotik dan ansiolitik golongan benzodiasepin yang berpotensi tidak tepat digunakan untuk pengobatan pada pasien usia lanjut. Usia lanjut khususnya yang sensitif dengan obat ini meningkatkan risiko kemunduran mental, delirium, jatuh, dan patah tulang. Hubungan antara penggunaan benzodiasepin dan terjadinya patah tulang panggul pada usia lanjut sudah banyak diteliti. Efek ketegangan mental terhadap risiko terjadinya fraktur tulang panggul pada usia lanjut dapat terjadi melalui beberapa mekanisme. Obat-obatan yang digunakan penderita yang mengalami ketegangan mental dapat menyebabkan penderita terganggu keseimbangannya dan meningkatkan risiko terjadinya jatuh, sebagai konsekuensinya risiko timbulnya fraktur tulang panggul meningkat. Mekanisme lain adalah ketegangan mental pada usia lanjut menyebabkan penderita mengabaikan kebiasaan untuk hidup sehat, misalnya banyak merokok dan makan makanan yang kurang gizi. Konsekuensinya, risiko timbulnya fraktur tulang panggul meningkat. Kemungkinan mekanisme lain adalah meningkatnya kortisol pada penderita ketegangan mental. Kortisol menyebabkan terjadinya osteoporosis, kortisol menghambat aktifitas osteoblas dan meningkatkan osteoklas yang mengakibatkan terganggunya proses keseimbangan dalam tulang. Akibatnya terjadilah kehilangan jaringan tulang dan meningginya risiko fraktur tulang panggul. Sehingga di rekomendasikan untuk menghindari penggunaan benzodiasepin (semua 
Identifikasi Penggunaan Obat Pada Pasien Diabetes Mellitus Tipe li Usia Lanjut Dengan Beer's Criteria Di Instalasi Rawat Inap Rumah Sakit Ibnu Sina Makassar Periode Tahun 2012

jenis) khususnya ketika perawatan terjadinya hipoglikemia. Sehingga di insomnia, agitasi atau delirium (kebingungan serius yang lama).

Insulin mempunyai peran yang sangat penting dan luas dalam pengendalian metabolisme. Insulin yang disekresikan oleh sel-sel $\beta$ pankreas akan langsung diinfusikan ke dalam hati melalui vena porta, yang kemudian akan di distribusikan ke seluruh tubuh melalui peredaran darah. Namun penggunaan insulin untuk usia lanjut sangat tidak efektif dan dapat meningkatkan kemungkinan gula darah menjadi sangat rendah (hipoglikemia) yaitu keadaan dimana kadar gula dalam darah $<60 \mathrm{mg} / \mathrm{dl}$ dan terjadi reaksi hipoglikemia yaitu glukosa darah turun mendadak, meskipun glukosa darah masih $>100$ $\mathrm{mg} / \mathrm{dl}$. Gejala yang muncul akibat hipoglikemia yaitu palpitasi, takikardia, mual muntah, lemah, dan dapat terjadi penurunan kesadaran sampai koma. Hipoglikemia pada pasien diabetes mellitus biasanya disebabkan oleh pemakaian insulin, kelebihan pemakaian dosis obat, ketidak teraturan penderita dalam hal mengkonsumsi makanan sehabis konsumsi obat, faktor usia lanjut dan adanya penyakit gagal ginjal kronik biasa merupakan faktor resiko rekomendasikan untuk menghindari penggunaannya pada usia lanjut.

Gliburid merupakan obat hipoglikemik oral golongan sulfonilurea dengan masa kerja panjang yang bekerja dengan merangsang sekresi insulin di kelenjar pankreas, sehingga hanya efektif pada penderita diabetes yang sel-sel $\beta$ pankreasnya masih berfungsi dengan baik. Dalam penggunaannya pada pasien usia lanjut dapat menyebabkan gula darah rendah (Hipoglikemia) yaitu apabila kadar gula darah lebih rendah dari 60 mg/dl. Gejala hipoglikemia seperti berdebar-debar, banyak berkeringat (biasanya keringat dingin), gemetar, terasa lapar, pusing, gelisah, dan kesadaran menurun hingga koma. Sama halnya dengan insulin, hipoglikemia juga dapat disebabkan oleh pemakaian obat antidiabetes (OAD) oral terutama golongan sulfonilurea salah satunya gliburid/glibenklamid. Sehingga di rekomendasikan untuk menghindari penggunaannya, khususnya untuk usia lanjut.

Metoklopramid merupakan obat antiemetik yang digunakan untuk mencegah atau mengurangi mual dan muntah akibat radiasi dan pasca 
Identifikasi Penggunaan Obat Pada Pasien Diabetes Mellitus Tipe li Usia Lanjut Dengan Beer's Criteria Di Instalasi Rawat Inap Rumah Sakit Ibnu Sina Makassar Periode Tahun 2012

bedah serta membantu pengosongan lambung dan meningkatkan perpindahan usus halus. Muntah biasanya disebabkan oleh perangsangan pada pusat muntah atau sering disebut chemoreseptor trigger zone (CTZ) sehingga menyebabkan kontraksi lambung. Metokloperamid umumnya bekerja menghambat rangsangan pada CTZ, umumnya cara kerja dari obat ini belum terlalu jelas, kemungkinan bekerja pada jaringan yang peka terhadap asetilkolin. Metoklopramid dapat meningkatkan tonus dan amplitudo pada kontraksi lambung (terutama pada bagian antrum), serta meningkatkan peristaltik dari duodenum dan jejunum sehingga dapat mempercepat pengosongan lambung dan usus. Tetapi penggunaannya pada pasien usia lanjut dapat menyebabkan kantuk, gerakan tubuh yang abnormal tak terkendali, dan lemah. Sehingga direkomendasikan untuk menghindari penggunaannya karena efek yang ditimbulkan.

Kalium diklofenak, asam mefenamat, ketorolak dan meloxicam merupakan golongan obat AINS (Antiinflamasi Non-Steroid) yang bekerja dengan menghambat enzim siklooksigenase

menyebabkan konversi asam arakhidonat menjadi PGG 2 menjadi terganggu sehingga mengurangi sensitifitas nyeri. Pemberian obat Asam mefenamat pada pasien usia lanjut tidak dianjurkan karena obat ini meningkatkan aktivitas perut dan pendarahan usus pada umur 75 atau lebih dan umur 65 tahun/ lebih. Efek samping pada saluran pencernaan terutama dilambung dan duodenum diakibatkan oleh penghambatan pada COX-1. Enzim tersebut bertanggung jawab dalam produksi prostaglandin, yang secara normal menghambat sekresi asam lambung. Prostaglandin berperan sebagai agen pereaksi mukosa terhadap asam lambung. AINS yang selektif menghambat COX2 menghasilkan efek samping pada lambung yang rendah. Namun AINS penghambat COX-2 pada jangka panjang juga berpotensi meningkatkan resiko thrombosis pada pasien dengan gangguan kardiovaskular. Selain dapat menyebabkan gangguan lambung (kembung, nyeri, keram, dan perdarahan lambung). Sehingga di rekomendasikan untuk tidak menggunakan obat ini secara teratur kecuali tidak ada alternatif efektif lainnya dan diresepkan untuk jangka 
Identifikasi Penggunaan Obat Pada Pasien Diabetes Mellitus Tipe li Usia Lanjut Dengan Beer's Criteria Di Instalasi Rawat Inap Rumah Sakit Ibnu Sina Makassar Periode Tahun 2012

panjang dengan penghambat pompa

\section{DAFTAR PUSTAKA}

proton/misoprostol.

\section{KESIMPULAN}

Dari penelitian yang dilakukan berdasarkan rekam medis pasien usia lanjut (60 tahun keatas) yang menjalani pengobatan penyakit diabetes mellitus tipe II di instalasi rawat inap Rumah Sakit Ibnu Sina Makassar periode tahun 2012 dapat disimpulkan bahwa jenis-jenis obat yang masuk ke dalam cakupan Beer's Criteria yaitu alprazolam sebesar $14,28 \%$, insulin 64,28\%, gliburid (gluconic $^{\circledR}$ ) $\quad 1,19 \%$, metoklopramid (sotatic $^{\circledR}$ ) 4,76\%, kal. Diklofenak (kataflam $^{\circledR}$ ) $1,19 \%$, asam mefenamat $3,57 \%$, meloxicam 2,38\%, dan ketorolak 8,33\%.

1. Direktorat Jenderal Bina Kefarmasian Dan Alat Kesehatan Departemen Kesehatan Republik Indonesia. Pedoman Pelayanan Farmasi (Tata Laksana Terapi Obat) Untuk Pasien Geriatric. Jakarta, 2006.

2. Ikawati Z, Januar GM, Raharjo B. Pengaruh pemberian Informasi Obat Berdasarkan Beers Criteria Terhadap Pola Pemberian Obat Pada Pasien Usia Lanjut Rawat Inap Penyakit Dalam Di RSUD Prof. Dr. Margono Soekarjo Purwokerto Periode Mei - Agustus 2010 (Skripsi). Yogyakarta: Universitas Gadjah Mada, 2010.

3. AGS. Identifying Medications that Older Adults Should Avoid or Use With Caution: the 2012 American Geriatrics SocietyUpdated Beers Criteria (Online), www.americangeriatrics.org. Diakses 5 Desember 2012, 2012. 